\title{
Korelasi Antara Rasa Ingin Tahu dan Motivasi Belajar dengan Hasil Belajar IPA Siswa Kelas V
}

\author{
Ni Kadek Ayu Dwi Arini ${ }^{1}$, I Nyoman Murda ${ }^{2}$, I Gusti Ayu Tri Agustiana ${ }^{3}$ \\ ${ }^{123}$ Prodi Pendidikan Guru Sekolah Dasar, FIP \\ Universitas Pendidikan Ganesha, \\ Singaraja, Indonesia \\ e-mail: kadekayudwiarini@gmail.com ${ }^{1}$, inyoman.murda@undiksha.ac.id², \\ Igustiayutriagustiana@yahoo.co.id ${ }^{3}$
}

\begin{abstract}
Abstrak
Penelitian ini bertujuan untuk mengetahui korelasi antara anatara rasa ingin tahu dan motivasi belajar dengan hasil belajar IPa. Jenis penelitian ini adalah penelitian ex-post facto. Populasi pada penelitian ini adalah siswa kelas V di SD Gugus I Pandu Jembrana Tahun yang berjumlah 159 orang. Pada penelitian ini menggunakan teknik sampel jenuh, sehingga keseluruhan dari populasi digunakan sebagai sampel. Metode pengumpulan data yang digunakan yaitu metode angket atau kuesioner dan pencatatan dokumen. Teknik analisis data yang digunakan adalah analisis deskriptif, analisis regresi sederhana, dan analisis regresi ganda. Hasil yang didapat menunjukkan: 1 ) terdapat korelasi yang positif dan signifikan antara rasa ingin tahu dengan hasil belajar IPA yang $r_{x 1}=0,817$ dan koefisien determinasinya sebesar $66,8 \%, 2$ ) terdapat korelasi yang positif dan signifikan antara motivasi belajar dengan hasil belajar IPA yang $r_{\mathrm{x} 2}=0,166$ dan koefisien determinasinya adalah $2,8 \%$,3) terdapat korelasi yang positif dan signifikan secara bersama-sama antara rasa ingin tahu dan motivasi belajar dengan hasil belajar IPA yang $r_{x 1 \times 2}=0,817$ dan koefisien determinasinya adalah $66,8 \%$. Jadi, terdapat korelasi yang positif dan signifikan secara bersama-sama antara rasa ingin tahu dan motivasi belajar dengan hasil belajar IPA siswa kelas V di SD Gugus I Pandu Jembrana.
\end{abstract}

Kata Kunci: hasil belajar IPA, motivasi belajar, rasa ingin tahu.

\begin{abstract}
The aimed of this study was to determine the correlation between: 1) curiosity with learning outcomes of natural science, 2) learning motivation with learning outcomes of natural science, and 3) at the sametime, curiosity and learning motivation with learning outcomes of natural science knowledge of Grade V students in Elementary School Cluster I Pandu Jembrana. This type of research was ex-post facto research. The population in this study was fifth grade students in Elementary School Cluster I Pandu Jembrana in academic year 2018/2019 which amounted to 159 students. This study used sensus sample technique, so all of the population was used as a sample. The data collection methods used questionnaire method and document recording. The data analysis technique used descriptive analysis, simple regression analysis, and multiple regression analysis. The results showed that : 1) there was a positive and significant correlation between curiosity and learning outcomes of natural science $r_{x 1}=0.817$ and the coefficient of determination was $66.8 \%$, 2) there was a positive and significant correlation between learning motivation and learning outcomes of natural science $r_{x 2}=0.166$ and the determination coefficient was $2.8 \%$, 3) at the same time, there was a positive and significant correlation between curiosity and learning motivation to learning outcomes of natural science which $r_{x 1 \times 2}=0.817$ and the coefficient of determination was $66.8 \%$. So it could be concluded that there was a positive and significant correlation between curiosity and learning motivation with the learning outcomes of natural science students of class V in Elementary School Cluster I Pandu.
\end{abstract}

Keywords: learning outcomes of natural science, learning motivation, curiosity.

${ }^{*}$ Corresponding author.

Received 20 January 2020, Accepted 20 March 2020; Available online 5 Appril 2020

(C) 2020 MI All Rights Reserved

Jurnal Mimbar IImu | 20 


\section{Pendahuluan}

Kualitas pendidikan berkaitan dengan kualitas siswa, karena titik pusat dalam pembelajaran adalah siswa. Siswa diharapkan dapat menimba ilmu dan wawasan yang sebanyak-banyaknya dengan belajar. Belajar merupakan suatu proses yang menimbulkan perubahan perilaku individu sebagai hasil dari pengalaman. Menurut Djamarah (2002: 12) belajar adalah suatu kegiatan yang dilakukan dengan melibatkan dua unsur, yaitu jiwa dan raga. Perubahan jiwa merupakan perubahan dari hasil proses belajar yang mempengaruhi tingkah laku seseorang. Berdasarkan pengertian belajar di atas, maka dapat diketahui bahwa, belajar adalah suatu kegiatan yang dilakukan oleh seseorang dengan sengaja dalam keadaan sadar untuk memperoleh pengetahuan berupa pemahaman maupun keterampilan baru, sehingga memungkinkan terjadinya perubahan perilaku yang relatif tetap. Terciptanya kegiatan belajar yang baik diperlukan proses pembelajaran yang relevan. Menurut Suprijono (2009) pembelajaran merupakan learning. Adapun pengertian pembelajaran berdasarkan makna leksikal berarti proses, cara, perbuatan mempelajari. Proses pembelajaran yang dibangun guru bermanfaat untuk mengembangkan kreatifitas berpikir yang dapat meningkatkan kemampuan berpikir siswa, serta dapat meningkatkan kemampuan mengkonstruksi pengetahuan baru sebagai upaya meningkatkan penguasaan yang baik terhadap materi pelajaran.

Banyak faktor-faktor yang mempengaruhi siswa dalam proses pembelajaran. Secara keseluruhan faktor-faktor yang ada, maka faktor tersebut dapat dibedakan menjadi dua yaitu, faktor internal dan faktor eksternal. Contoh dari faktor internal adalah kamauan yang terdapat dari dalam diri siswa sendiri untuk belajar, sedangkan faktor eksternal contohnya adalah lingkungan dan motivasi yang diberikan oleh orang lain, dan hal-hal lain yang berpengaruh terhadap siswa itu sendiri. Kedua faktor di atas sangat berpengaruh terhadap perkembangan siswa dalam belajar. Proses pembelajaran akan lebih bermakna dan tercapai dengan maksimal jika siswa memiliki dorongan dari faktor internal maupun eksternal, sesuai dengan apa yang dapat diketahui bahwa, siswa di sekolah dasar belajar tentang banyak mata pelajaran. Baik mata pelajaran pokok, maupun mata pelajaran tambahan lainnya, sehingga siswa memerlukan kemauan dari dirinya sendiri untuk belajar dan juga dorongan dari orang lain. Salah satu mata pelajaran pokok yang dipelajari siswa di sekolah dasar adalah mata pelajaran ilmu pengetahuan alam (IPA). IImu Pengetahuan Alam merupakan terjemahan kata-kata Inggris, yaitu natural science, artinya ilmu pengetahuan alam. Jadi, pengertiannya IPA dapat disebut sebagai ilmu tentang alam atau ilmu yang mempelajari tentang peristiwa-peristiwa yang terjadi di alam ini. IPA membahas tentang gejala-gejala alam yang disusun secara sistematis yang didasarkan pada hasil percobaan dan pengamatan yang dilakukan oleh manusia (Sumatowa dalam Muakhirin, 2014).

Kompleksnya pembelajaran IPA mengakibatkan mata pelajaran IPA kurang diminati oleh siswa oleh siswa, hal tersebut sejalan dengan hasil wawancara, observasi, dan pencatatan dokumen yang dilaksanakan pada tanggal 9 sampai dengan 21 Januari 2019. Berdasarkan kegiatan wawancara, observasi, dan pencatatan dokumen menunjukkan bahwa terdapat berbagai variasi masalah yang terjadi di sekolah, khususnya masalah dalam pelajaran IPA yang berhubungan dengan hasil belajar IPA. Hasil wawancara dengan wali kelas V menunjukkan bahwa, hasil belajar yang diperoleh dan tingkah laku yang ditunjukkan oleh siswa di dalam kelas, diakibatkan oleh perbedaan karakteristik yang dimiliki oleh masing-masing siswa. Perbedaan karakteristik siswa berkaitan dengan cepat lambatnya siswa dalam menerima materi pelajaran, sehingga ada siswa yang dapat dengan mudah menerima materi pembelajaran dan ada pula siswa yang sulit menerima materi pelajaran, sehingga hal tersebut mengakibatkan hasil belajar yang diperoleh siswa bervariasi.

Berdasarkan observasi yang dilakukan di dalam kelas, menunjukkan bahwa guru dalam melaksanakan proses pembelajaran menggunakan metode pembelajaran yang sama terhadap seluruh siswa yang mengikuti proses pembelajaran di kelas saat itu, dengan demikian maka seharusnya siswa memiliki hasil belajar yang sama, namun kenyataannya hasil belajar yang diperoleh siswa bervariasi. Hal tersebut terjadi karena proses pembelajaran yang terjadi di kelas cenderung berlangsung secara satu arah, siswa hanya menerima materi pelajaran dari 
guru tanpa adanya kegiatan bertanya mengenai hal-hal yang belum mereka pahami, siswa cenderung mengikuti perintah guru tanpa bertanya mengenai pembelajaran, dan siswa kurang aktif dalam menerima pelajaran. Kurangnya keaktifan siswa dalam belajar menunjukkan bahwa, rasa ingin tahu siswa siswa kurang terhadap pembelajaran IPA, karena masing-masing individu memiliki rasa ingin tahu yang berbeda-beda maka berakibat terhadap hasil belajar yang diperoleh siswa. Masalah lain dalam kegiatan pembelajaran yaitu, kurang fokusnya siswa karena pada saat kegiatan pembelajaran berlangsung siswa masih terlihat bermain dengan temannya, serta asyik dengan aktivitasnya sendiri ketika pembelajaran berlangsung, siswa tidak mengerjakan tugas yang diberikan oleh guru, siswa kurang berminat terhadap materi yang menuntut untuk menghafal, siswa memerlukan dorongan untuk mau tampil di depan kelas, siswa juga menganggap IPA merupakan pelajaran yang sulit, sehingga siswa tidak menyukai pembelajaran IPA. Kegiatan yang dilakukan siswa pada saat proses pembelajaran menunjukkan bahwa kurangnya motivasi yang dimiliki siswa terhadap mata pelajaran IPA.

Hasil belajar yang diperoleh siswa diketahui melalui pencatatan dokumen, dengan mengumpulkan data hasil belajar IPA siswa kelas V berupa nilai ulangan harian di SD Gugus I Pandu. Hal ini dapat dilihat pada Tabel 01.

Tabel 01

Nilai ulangan harian IPA pada siswa kelas V di SD Gugus I Pandu

\begin{tabular}{|c|c|c|c|c|c|c|c|}
\hline \multirow[b]{2}{*}{ Nama Sekolah } & & \multicolumn{5}{|c|}{ Kategori Skor } & \multirow[b]{2}{*}{$\begin{array}{l}\text { Jumlah } \\
\text { Siswa }\end{array}$} \\
\hline & & $\begin{array}{c}\text { Sangat } \\
\text { Baik }\end{array}$ & Baik & Cukup & Kurang & $\begin{array}{l}\text { Sangat } \\
\text { Kurang }\end{array}$ & \\
\hline $\begin{array}{l}\text { SDN } \\
\text { Sangkaragung }\end{array}$ & 1 & 3 & 17 & 4 & - & - & 24 \\
\hline $\begin{array}{l}\text { SDN } \\
\text { Sangkaragung }\end{array}$ & 2 & - & 6 & 4 & 1 & - & 11 \\
\hline SDN 1 Yehkuning & & 1 & 12 & 8 & - & - & 21 \\
\hline SDN 2 Yehkuning & & - & 8 & 7 & 2 & - & 17 \\
\hline SDN 1 Airkuning & & - & 12 & 3 & 1 & - & 16 \\
\hline SDN 2 Airkuning & & - & 5 & 4 & 3 & - & 12 \\
\hline SDN 1 Perancak & & 1 & 15 & 6 & 2 & - & 24 \\
\hline SDN 2 Perancak & & 2 & 17 & 10 & 5 & - & 34 \\
\hline Jumlah & & 7 & 92 & 46 & 14 & - & 159 \\
\hline
\end{tabular}

Berdasarkan Tabel 1 dapat diketahui kategori nilai yang diperoleh siswa kelas $\mathrm{V}$ di SD yang ada pada Gugus I Pandu. Tabel tersebut menunjukkan bahwa berdasarkan data yang diperoleh terdapat nilai yang bervariasi, ada yang sangat baik, baik, cukup, dan kurang. Kategori nilai tersebut mengacu pada Penilaian Acuan Patokan (PAP) skala 5 menurut Agung (2016: 146). Proses pembelajaran aktif yang terjadi di dalam kelas dapat terealisasi ketika siswa memiliki rasa ingin tahu dan motivasi belajar yang memicu dirinya untuk berperan aktif dalam proses pembelajaran. Maka dari itu, diperlukannya penenanaman rasa ingin tahu dan motivasi belajar oleh guru dengan memberikan proses pembelajar inovatif kepada siswa, agar dapat meningkatkan hasil belajar.

Berdasarkan ciri umum siswa SD menurut Baseet et al. (dalam Agustiana dan Tika, 2017) meyatakan bahwa secara alamiah siswa SD memiliki rasa ingin tahu yang kuat dan tertarik akan dunia sekitar yang mengelilingi diri mereka sendiri. Menurut persepsi anak, dunia ini dipenuhi dengan hal-hal yang menarik dan menakjubkan. Hal itulah yang mengakibatkan anak memiliki rasa keingintahuan yang sangat tinggi. Rasa ingin tahu sangatlah bervariasi, tergantung apa yang menarik perhatiannya. Rasa ingin tahu merupakan salah satu faktor internal yang mempengaruhi hasil belajar siswa. Rasa ingin tahu merupakan modal awal bagi siswa dalam proses pembelajaran. Menurut Mustari (2014: 85) bahwa, kurioritas (rasa ingin tahu) adalah emosi yang dihubungkan dengan perilaku mengorek secara alamiah seperti 
eksplorasi, investigasi, dan belajar. Ghufron \& Risnawati S (2016) juga menyatakan bahwa, rasa ingin tahu merupakan suatu sikap mental yang membuat seseorang selalu terdorong untuk mengetahui lebih banyak, selalu mengajukan banyak pertanyaan, selalu memerhatikan orang, objek, dan situasi serta peka dalam pengamatan. Adanya keinginan untuk meneliti maupun mengetahui tentang segala sesuatu. Rasa ingin tahu yang dimiliki oleh siswa dimanifestasikan dalam perilaku yang berupa, (1) mempertanyakan segala sesuatu; (2) senang menjajaki buku-buku, peta-peta, gambar-gambar, dan sebagainya untuk mencoba sesuatu yang belum dikenal; (3) tidak membutuhkan dorongan untuk menjajaki atau mencoba sesuatu yang belum dikenal; (4) menggunakan semua panca indra untuk mengenal; (5) tidak takut menjajaki bidang-bidang baru; (6) ingin mengamati perubahan-perubahan dari hal-hal atau kejadian; (7) ingin bereksperimen dengan benda-benda mekanik. Berdasarkan penjelasan tersebut dapat diketahui, bahwa dengan adanya rasa ingin tahu pada diri siswa akan sangat mempengaruhi siswa dalam kegiatan pembelajaran, sehingga dapat mendorong siswa untuk belajar dan mendapatkan hasil belajar yang maksimal.

Faktor lainnya yang mempengaruhi hasil belajar selain rasa ingin tahu adalah motivasi belajar. Motivasi belajar berperan penting dalam keberhasilan siswa untuk menghasilkan hasil belajar yang maksimal. Tanpa adanya motivasi belajar dalam diri siswa, tidak mungkin siswa tersebut akan mendapatkan hasil belajar yang maksimal. Menurut Uno (2008: 3) motivasi merupakan dorongan yang terdapat dalam diri seseorang untuk berusaha mengadakan perubahan tingkah laku yang baik dalam memenuhi kebutuhannya. Menurut Sardiman (2011: 75) motivasi belajar merupakan keseluruhan daya penggerak di dalam diri siswa yang menimbulkan kegiatan belajar, yang menjamin kelangsungan dari kegiatan belajar dan yang memberikan arah pada kegiatan belajar, sehingga tujuan yang dikehendaki oleh subjek belajar itu dapat tercapai. Motivasi belajar tinggi akan dimiliki seseorang, jika ia menyadari dan memahami tujuan yang akan dicapainya di kemudian hari. Seseorang yang memahami citacitanya dengan baik, maka ia akan terdorong untuk semakin giat dalam belajar. Motivasi merupakan daya yang dapat menggerakkan diri siswa agar mau belajar, menjamin kelangsungan kegiatan belajar, mengarahkan siswa dalam kegiatan belajar, sehingga siswa dapat mencapai tujuan dalam belajar.

Jika dikaitkan dengan pembelajaran IPA di sekolah dasar, motivasi intrinsik siswa akan mengakibatkan siswa tertarik ingin mempelajari serta melakukan apapun yang berhubungan dengan pengetahuan alam atas dasar keinginan dan kemauannya sendiri. Motivasi ekstrinsik adalah motif-motif yang aktif dan berfungsi jika adanya perangsang dari luar. Motivasi dari luar diri siswa yang berkaitan dengan pelajaran IPA yaitu melakukan suatu kegiatan-kegiatan yang dipengaruhi oleh orang tua, teman, orang yang ada disekitarnya, maupun tugas yang diberikan oleh guru. Motivasi akan timbul dari diri siswa apabila semakin relevan tugas yang diberikan. Adanya motivasi yang tinggi diharapkan mampu menggerakkan siswa untuk menjadikan belajar bukan hanya sebagai tuntutan, namun juga merupakan kebutuhan bagi dirinya. Motivasi memiliki peran penting dalam kegiatan belajar siswa, seperti yang diungkapkan Uno (2008: 27) bahwa motivasi memiliki peran penting dalam belajar dan pembelajaran, antara lain dalam (a) menentukan hal-hal yang dapat dijadikan penguat belajar, (b) memperjelas tujuan belajar yang hendak dicapai, (c) menentukan ragam kendali terhadap rangsangan belajar, (d) menentukan ketekunan belajar.

Berdasarkan pemaparan di atas, pembelajaran yang didukung oleh siswa yang memiliki rasa ingin tahu dan motivasi belajar dapat berperan untuk mempengaruhi tingkat pencapaian hasil belajar siswa dalam mata pelajaran IPA, sehingga tujuan pembelajaran dapat tercapai. Oleh sebab itu, penelitian ini dilakukan untuk, (1) mengetahui korelasi antara rasa ingin tahu siswa dengan hasil belajar IPA siswa kelas V di SD Gugus I Pandu Jembrana tahun pelajaran 2018/2019, (2) mengetahui korelasi antara motivasi belajar dengan hasil belajar IPA siswa kelas V di SD Gugus I Pandu Jembrana tahun pelajaran 2018/2019, (3) mengetahui korelasi antara rasa ingin tahu dan motivasi belajar dengan hasil belajar IPA siswa kelas V di SD Gugus I Pandu Jembrana Tahun Pelajaran 2018/2019. 


\section{Metode}

Penelitian ini pada dasarnya bertujuan untuk mengetahui korelasi antara rasa ingin tahu dan motivasi belajar terhadap hasil belajar IPA siswa kelas V di SD Gugus I Pandu Jembrana tahun pelajaran 2018/2019. Penelitian ini termasuk tipe penelitian "ex-post facto" karena tidak memanipulasi keadaan variabel yang ada dan langsung mencari keberadaan hubungan dan tingkat hubungan variabel. Menurut Kerlinger (dalam Sukardi, 2012) penelitian ex-post facto merupakan penelitian variabel-variabel bebas telah terjadi karena penelitian dimulai dengan pengamatan variabel terikat dalam suatu penelitian. Penelitian ex-post facto dilakukan untuk meneliti peristiwa yang terjadi yang kemudian meruntut ke belakang untuk mengetahui faktorfaktor yang menimbulkan kejadian tersebut. Penelitian ini termasuk ke dalam jenis penelitian korelasi. Menurut Gay (dalam Sukardi, 2012) penelitian korelasi adalah suatu penelitian yang melibatkan tindakan pengumpulan data guna menentukan, apakah ada hubungan dan tingkat hubungan antara dua variabel atau lebih. Penelitian korelasi, seperti yang dikatakan Gay (dalam Sukardi, 2012), merupakan salah satu bagian penelitian ex-post facto karena biasanya penelitian dilakukan dengan tidak memanipulasi keadaan variabel yang ada dan langsung mencari keberadaan hubungan dan tingkat hubungan variabel yang direfleksikan dalam koefisien korelasi.

Langkah awal yang perlu dilakukan untuk menentukan subjek penelitian adalah menentukan populasi yang akan diteliti. Populasi berkaitan dengan keselutuhan objek yang akan diteliti. Menurut Sukardi (2012) populasi pada prinsipnya adalah semua anggota kelompok manusia, binatang, peristiwa, atau benda yang tinggal bersama dalam satu tempat dan secara terencana menjadi target kesimpulan dari hasil akhir suatu penelitian. Agung (2014) menyatakan populasi adalah keseluruhan objek dalam suatu penelitian. Berdasarkan pengertian para ahli di atas, dapat disimpulkan bahwa populasi merupakan seluruh data yang meliputi manusia, binatang, peristiwa, atau benda dalam suatu ruang lingkup dan terencana menjadi target penelitian. Populasi dalam penelitian ini adalah seluruh siswa kelas $\mathrm{V}$ di SD Gugus I Pandu Jembrana tahun pelajaran 2018/2019. Populasi terdiri dari 159 siswa yang terdapat pada delapan SD yang ada di Gugus I Pandu Jembrana antara lain, SDN 1 Sangkaragung, SDN 2 Sangkaragung, SDN 1 Yehkuning, SDN 2 Yehkuning, SDN 1 Airkuning, SDN 2 Airkuning, SDN 1 Perancak, dan SDN 2 Perancak.

Berdasarkan populasi yang telah ditentukan, maka selanjutnya diambil perwakilan yang dianggap mewakili seluruh populasi. Perwakilan dari keseluruhan populasi dan ditentukan dengan menggunakan teknik tertentu disebut dengan sampel. Kelompok kecil yang secara nyata diteliti dan ditarik kesimpulan dari padanya disebut sampel (Sukmadinata, 2009). Koyan (2012: 30) menyatakan bahwa sampel adalah bagian dari populasi. Teknik yang digunakan mengambil sampel dari populasi disebut "teknik sampling" (Ali dalam Agung, 2014). Teknik pengambilan sampel yang digunakan dalam penelitian ini adalah sampling jenuh, karena penelitian ini menggunakan seluruh anggota populasi sebagai sampel. Hal tersebut sejalan dengan pendapat Sugiyono (2012) yang menyatakan bahwa, sampling jenuh adalah teknik penentuan sampel bila semua anggota populasi digunakan sebagai sampel. Berdasarkan hal tersebut, maka jumlah sampel pada penelitian ini adalah 159, sesuai dengan jumlah keseluruhan populasi yang ada.

Dalam penelitian ini terdapat 3 variabel, yaitu dua variabel bebas dan satu variabel terikat. Variabel bebas yang pertama $\left(X_{1}\right)$ adalah rasa ingin tahu dan variabel bebas yang kedua $\left(\mathrm{X}_{2}\right)$ adalah motivasi belajar, sedangkan variabel terikatnya $(\mathrm{Y})$ adalah hasil belajar IPA. Adapun metode pengumpulan data pada penelitian ini yaitu: 1) kuesioner atau angket dengan memberikan pertanyaan yang dijawab oleh siswa dengan mengukur daya ketahanmalangan dan minat belajar, 2) pencatatan dokumen berupa nilai akhir semester I (ganjil) tahun pelajaran 2018/2019 siswa kelas V di SD Gugus I Pandu Jembrana. Instrumen yang digunakan untuk pengumpulan data adalah kuesioner atau angket yang digunakan sebagai alat pengumpulan data yang dirancang. Menurut Sugiyono (2012: 199) kuesioner merupakan teknik pengumpulan data yang dilakukan dengan cara memberi seperangkat pertanyaan atau pernyataan tertulis kepada responden untuk dijawab. Penelitian ini menggunakan dua jenis kuesioner atau angket 
yaitu rasa ingin tahu dan motivasi belajar. Dalam setiap pernyataan terdapat pernyataan yang positif dan negatif. Penskoran dalam angket rasa ingin tahu motivasi belajar menggunakan skala Likert. Menurut Sugiyono (2012: 134) skala Likert digunakan untuk mengukur sikap, pendapat, dan persepsi seseorang atau sekelompok orang tentang fenomena sosial. Jawaban setiap item instrument yang menggunakan skala likert mempunyai garadasi dari sangat positif sampai sangat negatif, yang dapat berupa kata-kata sangat setuju, setuju, ragu-ragu, tidak setuju, dan sangat tidak setuju.

Sebelum mengumpulkan data dengan menyebarkan kuesioner atau angket, terlebih dahulu melakukan uji coba instrumen penelitian untuk mengetahui apakah kueisoner atau angket layak digunakan atau tidak. Pernyataan-pernyataan angket rasa ingin tahu dan motivasi belajar yang dibuat sendiri dengan mengembangkan soal angket dari ahli masing-masing dan telah diuji validitas secara empirik oleh expert judges. Lalu dari hasil uji instrumen yang meliputi uji validitas dan uji reliabilitas diperoleh hasil bahwa seluruh pernyataan yang berjumlah 30 pernyataan dinyatakan layak untuk mengukur rasa ingin tahu dan motivasi belajar siswa. Teknik analisis data yang digunakan yaitu uji prasyarat analisis dan uji hipotesis. Uji hipotesis yang digunakan dalam penelitian ini adalah analisi regresi sederhana dan analisis regresi ganda. Sebelum melakukan uji hipotesis, data penelitian harus memenuhi uji prasyarat analisis terlebih dahulu yaitu yang pertama uji normalitas. Rasa ingin tahu $\left(X_{1}\right)$ memperoleh nilai kolmogorov-smirnov= 0,084 $>0,05$ maka dapat disimpulkan bahwa data rasa ingin tahu berdistribusi normal. Motivasi belajar $\left(\mathrm{X}_{2}\right)$ memperoleh nilai kolmogorov-smirnov= 0,200 >0,05 maka dapat disimpulkan bahwa data motivasi belajar berdistribusi normal. Hasil belajar IPA (Y) memperoleh nilai kolmogorov-smirnov= 0,200 > 0,05 maka dapat disimpulkan bahwa data hasil belajar IPA berdistribusi normal.

Selanjutnya uji linieritas, pada rasa ingin tahu dengan hasil belajar IPA menunjukkan bahwa angka signifikansi Linierity sebesar $0,00(p<0,05)$ sehingga rasa ingin tahu dengan hasil belajar IPA memiliki hubungan yang linier. Sedangkan signifikansi Deviation from Linierity sebesar 0,157 ( $p>0,05)$ sehingga rasa ingin tahu dengan hasil belajar IPA memiliki hubungan yang berarti. Pada motivasi belajar dengan hasil belajar IPA menunjukkan bahwa angka signifikansi Linierity sebesar $0,031(p<0,05)$ sehingga motivasi belajar dengan hasil belajar IPA memiliki hubungan yang linier. Sedangkan signifikansi Deviation from Linierity sebesar 0,157 $(p>0,05)$ sehingga motivasi belajar dengan hasil belajar IPA memiliki hubungan yang berarti.

Selanjutnya uji multikolinieritas, kriteria pengujian uji multikolinieritas adalah Jika $\mathrm{rx}_{1} \mathrm{x}_{2}<$ 0,800 maka antar sesama variabel bebas dinyatakan menerima $\mathrm{HO}$ atau tidak terjadi multikolinieritas. Sebaliknya jika $\mathrm{rx}_{1} \mathrm{x}_{2}>0,800$ maka antar sesama variabel dinyatakan menerima $\mathrm{Ha}$ atau terjadi multikolinieritas. Berdasarkan hasil analisis uji multikolinieritas diperoleh harga $r x_{1} x_{2} 0,197<0,800$ sehingga antara sesama variabel bebas rasa ingin tahu $\left(X_{1}\right)$ dan motivasi belajar $\left(\mathrm{X}_{2}\right)$ tidak terjadi multikolinieritas atau menerima $\mathrm{H}_{0}$.

Selanjutnya dilakukan uji autokorelasi. Berdasarkan hasil analisis uji autokorelasi, diperoleh Durbin-Watson sebesar 1,782. Hasil analisis Durbin-Watson mendekati 2, sehingga dapat ditarik kesimpulan data penelitian tidak terjadi autokorelasi. Uji prasyarat yang terakhir yaitu uji heterokedastisitas. Kriteria pengujian heterokedastisitas yaitu jika pada grafik tampak titik-titik menyebar di atas dan di bawah sumbu Y, maka tidak terjadi heterokedastisitas. Namun jika pada grafik tampak titik-titik membentuk pola tertentu maka terjadi heterokedastisitas. Berdasarkan hasil analisis uji heterokedastisitas diperoleh hasil pada Gambar 1. 


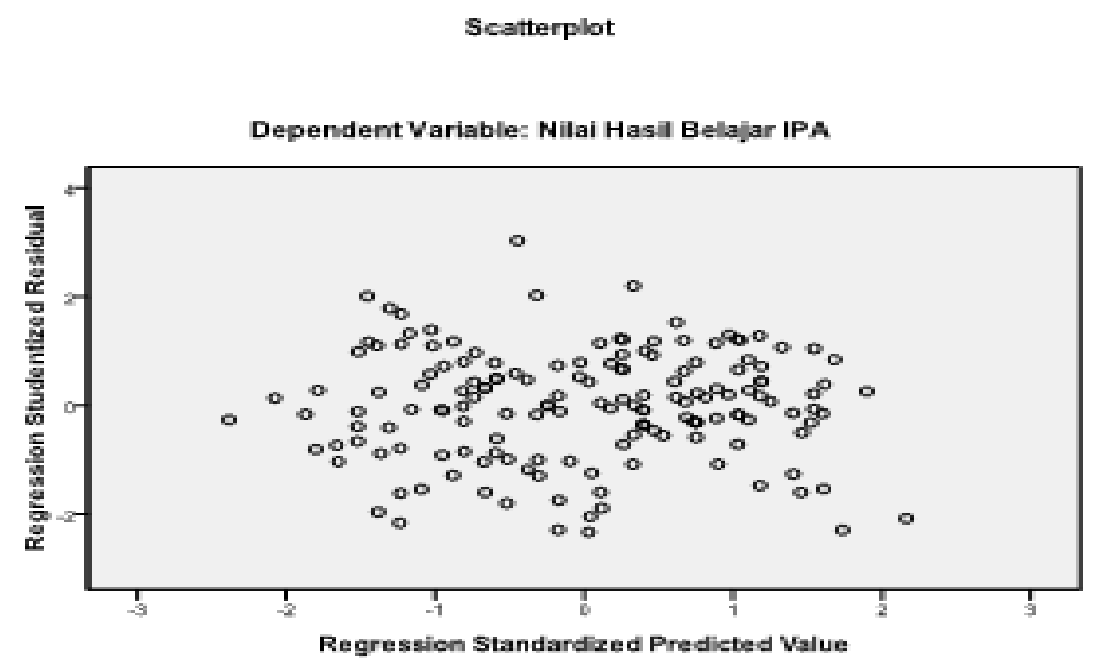

Gambar 1. Hasil uji heterokedastisitas

Pada Gambar 1 menunjukkan diagram pencar yang terlihat titik-titik (bulatan-bulatan kecil) menyebar dan tidak membentuk pola tertentu. Hal itu menunjukkan bahwa tidak terjadi heterokedastisitas. Sehingga data bisa dilanjutkan ke analisis regresi.

\section{Hasil dan Pembahasan}

Deskripsi data hasil penelitian memaparkan tentang rasa ingin tahu $\left(\mathrm{X}_{1}\right)$ dan motivasi belajar $\left(\mathrm{X}_{2}\right)$ dengan hasil belajar IPA $(\mathrm{Y})$. Setelah mendapatkan deskripsi data setiap variabel, selanjutnya adalah uji hipotesis. Pada hipotesis pertama antar variabel rasa ingin tahu dengan hasil belajar IPA diperoleh nilai koefisien korelasi seperti Tabel 02.

\section{Tabel 02}

Hasil analisis regresi sederhana $X_{1}{ }^{*} Y$

\section{Correlations}

\begin{tabular}{llll} 
& & \multicolumn{1}{c}{$\begin{array}{c}\text { Nilai Hasil } \\
\text { Belajar IPA }\end{array}$} & $\begin{array}{c}\text { Angket Rasa } \\
\text { Ingin Tahu }\end{array}$ \\
\hline Pearson Correlation & Nilai Hasil Belajar IPA & 1.000 & .817 \\
& Angket Rasa Ingin Tahu & .817 & 1.000 \\
Sig. (1-tailed) & Nilai Hasil Belajar IPA &. & .000 \\
$\mathrm{~N}$ & Angket Rasa Ingin Tahu & .000 &. \\
& Nilai Hasil Belajar IPA & 159 & 159 \\
& Angket Rasa Ingin Tahu & 159 & 159 \\
\hline
\end{tabular}

Dari hasil perhitungan menggunakan bantuan program SPSS 17.0 For Windows pada Tabel 2 diperoleh nilai koefisien korelasi senilai 0,817 dengan signifikan sebesar 0,000. Hal ini berarti nilai signifikannya lebih kecil dari 0,05 maka nilai korelasi tersebut signifikan. 


\section{Tabel 03}

Hasil analisis besar koefisien korelasi $\mathrm{X}_{1}{ }^{*} \mathrm{Y}$

\begin{tabular}{|c|c|c|c|c|c|c|}
\hline \multicolumn{7}{|c|}{ ANOVA $^{b}$} \\
\hline & Model & $\begin{array}{l}\text { Sum of } \\
\text { Squares }\end{array}$ & df & Mean Square & $\mathbf{F}$ & Sig \\
\hline \multirow[t]{3}{*}{1} & Regression & 4226.854 & 1 & 4226.854 & 316.072 & $.000^{\mathrm{a}}$ \\
\hline & Residual & 2099.573 & 157 & 13.373 & & \\
\hline & Total & 6326.428 & 158 & & & \\
\hline
\end{tabular}

Pada Tabel 03 menunjukkan bahwa harga $F_{\text {hitung }}$ sebesar 316,072. Kaidah keputusannya adalah dengan menggunakan $a=0,05$ dengan $d k=1:(n-2)$, jika $F_{\text {hitung }}>F_{\text {tabel }}(0,05)$, maka garis regresi tersebut signifikan. Berdasarkan hal tersebut diperoleh $F_{\text {hitung }} 316,072>F_{\text {tabel }} 3,05$ maka dapat ditarik kesimpulan garis regresi bersifat signifikan. Sehingga $\mathrm{H}_{0}$ yang berbunyi tidak terdapat hubungan yang positif dan signifikan antara rasa ingin tahu dengan hasil belajar IPA siswa kelas V di SD Gugus I Pandu Jembrana Tahun Pelajaran 2018/2019 ditolak, dan $\mathrm{H}_{a}$ diterima. Adapun sumbangan koefisien determinasinya sebesar $66,8 \%$ dengan persamaan garis regresi $Y=36,520+0,367 X_{1}$.

Pada hipotesis kedua antar variabel motivasi belajar dengan hasil belajar IPA diperoleh nilai koefisien korelasi seperti Tabel 04.

\section{Tabel 04}

Hasil analisis regresi sederhana $\mathrm{X}_{2}{ }^{*} \mathrm{Y}$

\section{Correlations}

\begin{tabular}{llll} 
& & \multicolumn{1}{c}{$\begin{array}{c}\text { Nilai Hasil } \\
\text { Belajar IPA }\end{array}$} & \multicolumn{1}{c}{$\begin{array}{c}\text { Angket Motivasi } \\
\text { Belajar }\end{array}$} \\
\hline Pearson Correlation & Nilai Hasil Belajar IPA & 1.000 & .166 \\
& Angket Motivasi Belajar & .166 & 1.000 \\
Sig. (1-tailed) & Nilai Hasil Belajar IPA &. & .018 \\
& Angket Motivasi Belajar & .018 &. \\
$\mathrm{~N}$ & Nilai Hasil Belajar IPA & 159 & 159 \\
& Angket Motivasi Belajar & 159 & 159 \\
\hline
\end{tabular}

Dari hasil perhitungan menggunakan bantuan program SPSS 17.0 For Windows pada Tabel 04 diperoleh nilai koefisien korelasi senilai 0,166 dengan signifikan sebesar 0,018. Hal ini berarti nilai signifikannya lebih kecil dari 0,05 maka nilai korelasi tersebut signifikan.

Tabel 05

Hasil analisis besar koefisien korelasi $X_{2}{ }^{*} Y$

\begin{tabular}{|c|c|c|c|c|c|c|}
\hline \multicolumn{7}{|c|}{ ANOVA $^{b}$} \\
\hline & Model & Sum of Squares & $\mathrm{df}$ & Mean Square & $\mathrm{F}$ & Sig. \\
\hline \multirow[t]{3}{*}{1} & Regression & 174.803 & 1 & 174.803 & 4.461 & $.036^{a}$ \\
\hline & Residual & 6151.625 & 157 & 39.182 & & \\
\hline & Total & 6326.428 & 158 & & & \\
\hline
\end{tabular}


Berdasarkan hal tersebut diperoleh $F_{\text {hitung }} 4,461>F_{\text {tabel }}$ 3,05 maka dapat ditarik kesimpulan garis regresi bersifat signifikan. Sehingga $\mathrm{H}_{0}$ yang berbunyi tidak terdapat hubungan yang positif dan signifikan antara motivasi belajar dengan hasil belajar IPA siswa kelas V di SD Gugus I Pandu Jembrana Tahun Pelajaran 2018/2019 ditolak, dan $\mathrm{H}_{\mathrm{a}}$ diterima. Adapun sumbangan koefisien determinasinya sebesar $2,8 \%$ dengan persamaan garis regresi $\mathrm{Y}=67,562+0,097 \mathrm{X}_{2}$.

Pada hipotesis ketiga antar variabel secara bersama-sama antara rasa ingin tahu dan motivasi belajar dengan hasil belajar IPA diperoleh hasil seperti Tabel 6.

\section{Tabel 06}

Hasil analisis besar koefisien regresi ganda $X_{1} X_{2}{ }^{*} Y$

\section{ANOVA $^{b}$}

\begin{tabular}{lllllll} 
& Model & Sum of Squares & df & Mean Square & $F$ & Sig. \\
\hline 1 & Regression & 4227.030 & 2 & 2113.515 & 157.049 & $.000^{\mathrm{a}}$ \\
& Residual & 2099.398 & 156 & 13.458 & & \\
Total & 6326.428 & 158 & & & \\
\hline
\end{tabular}

Pada Tabel 6 menunjukkan bahwa harga $F_{\text {hitung }}$ sebesar 157,049 dengan signifikansi 0,000 . Kaidah keputusannya adalah dengan menggunakan $a=0,05$ dengan $\mathrm{dk}=1:(\mathrm{n}-2)$, jika $F_{\text {hitung }}>F_{\text {tabel }}(0,05)$, maka garis regresi tersebut signifikan. Sehingga $\mathrm{H}_{0}$ yang berbunyi tidak terdapat hubungan yang positif dan signifikan secara bersama-sama antara rasa ingin tahu dan motivasi belajar dengan hasil belajar IPA siswa kelas V di SD Gugus I Pandu Jembrana Tahun Pelajaran 2018/2019 ditolak, dan $\mathrm{H}_{\mathrm{a}}$ diterima. Adapun nilai koefisien kontribusi yaitu 0,817. Jadi dapat disimpulkan bahwa $\mathrm{r}_{\text {hitung }} 0,817>\mathrm{r}_{\text {tabel }}$ 0,156 maka $\mathrm{H}_{0}$ ditolak yang berarti signifikan. Adapun besar koefisien determinasinya adalah $66,8 \%$ dengan persamaan garis regresi $Y=$ $36,197+0,367 X_{1}+0,003 X_{2}$.

Berdasarkan hasil penelitian dan perhitungan yang telah dilakukan, menggunakan bantuan program SPSS 17.0 For Windows, dapat disimpulkan bahwa hipotesis pertama yang berbunyi "terdapat korelasi yang positif dan signifikan antara rasa ingin tahu $\left(\mathrm{X}_{1}\right)$ dengan hasil belajar IPA (Y) siswa kelas V di SD Gugus I Pandu Jembrana Tahun Pelajaran 2018/2019" dinyatakan diterima, dengan koefisien korelasi sebesar 0,817 dengan signifikan 0,000. Hal ini berarti nilai signifikan sebesar 0,000 lebih kecil dari 0,05 sehingga nilai korelasi tersebut signifikan. Diperoleh persamaan garis regresi $Y=36,520+0,367 X_{1}$ dengan $F_{\text {hitung }}=316,072$ dan sumbangan rasa ingin tahu yang dimiliki siswa dengan hasil belajar IPA sebesar $66,8 \%$. Dalam penelitian ini ditemukan korelasi yang positif dan signifikan yang berarti semakin tinggi rasa ingin tahu siswa maka semakin tinggi hasil belajar IPA siswa. Siswa yang memiliki rasa ingin tahu yang tinggi akan lebih mampu dalam menghadapi kesulitan belajar terutama dalam belajar IPA, serta akan selalu berusaha menemukan jawaban hingga berhasil. Hal tersebut sejalan dengan pendapat Baseet et al (dalam Agustiana dan Tika, 2017) yang menyatakan salah satu ciri umum siswa SD yaitu secara alamiah memiliki rasa ingin tahu yang kuat dan tertarik akan dunia sekitar yang mengelilingi diri mereka sendiri. Kuatnya rasa ingin tahu yang dimiliki siswa serta ketertarikan akan dunia sekitar akan menimbulkan niat atau tekad, karena tekad itulah akan ada usaha untuk mencapai tujuan secara maksimal. Keberhasilan siswa dalam mencapai hasil belajar IPA diperlukan penguasaan materi dalam proses pembelajaran yang didorong dengan adanya rasa ingin tahu. Adanya rasa ingin tahu yang berbeda antara siswa satu dengan yang lainnya akan memberikan berbagai macam pengetahuan IPA yang berbeda. Apabila seseorang siswa mempunyai rasa ingin tahu yang baik dalam kegiatan pembelajaran IPA, siswa akan mampu partisipasi aktif, seperti sering membaca, berdiskusi, maupun bertanya mengenai materi yang terdapat dari berbagai sumber. Hal tersebut sejalan dengan pendapat Kashdan dan Silvia (dalam Sugianto, 2018) yang menyatakan curiosity adalah sebuah pengakuan, pencarian, dan keinginan yang kuat untuk mengeksplorasi hal baru 
yang menantang dan tidak pasti. Dengan hal tersebut siswa mampu memahami pembelajaran dengan baik dan dapat meningkatkan hasil belajar IPA.

Dilakukan pula penelitian tentang motivasi belajar siswa yang dianalisis menggunakan bantuan program SPSS 17.0 For Windows, dapat disimpulkan bahwa hipotesis kedua yang berbunyi "terdapat korelasi yang positif dan signifikan antara motivasi belajar $\left(\mathrm{X}_{2}\right)$ dengan hasil belajar IPA (Y) siswa kelas V di SD Gugus I Pandu Tahun Pelajaran 2018/2019" dinyatakan diterima, dengan koefisien korelasi sebesar 0,166 dengan signifikan 0,018. Hal ini berarti nilai signifikan sebesar 0,018 lebih kecil dari 0,05 sehingga nilai korelasi tersebut signifikan. Diperoleh persamaan garis regresi $Y=67,562+0,097 X_{2}$ dengan $F_{\text {hitung }}=4,461$ dan sumbangan rasa ingin tahu yang dimiliki siswa dengan hasil belajar IPA sebesar 2,8\%.

Dalam penelitian ini ditemukan korelasi yang positif dan signifikan yang berarti semakin tinggi motivasi belajar siswa maka semakin tinggi hasil belajar IPA siswa. Kecilnya sumbangan motivasi belajar dengan hasil belajar IPA pada penelitian ini disebabkan oleh adanya kelemahan-kelamahan yang dimiliki siswa dari faktor internal maupun eksternal. Berdasarkan hasil kuesioner diketahui terdapat kelamahan pada indikator yang ke 6 yang menyatakan adanya lingkungan yang kondusif, sehingga dapat diketahui bahwa kurang adanya lingkungan yang kondusif yang dapat memotivasi siswa dalam belajar. Contohnya adalah karena adanya cuaca yang panas saat belajar, sehingga siswa tidak berkonsentrasi, kurang adanya lingkungan yang sejuk yang dapat membuat siswa nyaman dalam belajar, kotornya ruangan kelas pada saaat belajar, gangguan dari pihak lain seperti adik kelas maupun kakak kelasnya dalam belajar, dan keributan kelas lain yang dapat menimbulkan ketidaknyamanan dalam belajar. Motivasi adalah gejala psikologis dalam bentuk dorongan yang timbul pada diri seseorang sadar atau tidak sadar untuk melakukan suatu tindakan dengan tujuan tertentu. Adapun peranan penting dari motivasi dalam belajar dan pembelajaran menurut Uno (2008), antara lain dalam (a) menentukan hal-hal yang dapat dijadikan penguat belajar, (b) memperjelas tujuan belajar yang hendak dacapai, (c) menentukan ragam kendali terhadap rangsangan belajar, (d) menentukan ketekunan belajar. Dengan memiliki motivasi belajar akan memudahkan siswa dalam melaksanakan pembelajaran di dalam kelas, karena motivasi tersebut akan mendorong dirinya untuk semangat dalam belajar. Hal serupa juga dikemukakan oleh Hamalik (2009) yang mengemukakan bahwa motivasi dapat berfungsi sebagai pendorong timbulnya kelakuan atau suatu perbuatan. Tanpa motivasi maka tidak akan timbul sesuatu perbuatan seperti belajar. Maka dari itu motivasi peran penting dalam belajar. Siswa akan melakukan sesuatu karena adanya motivasi di dalam dirinya. Maka dari itu, dengan adanya usaha yang tekun yang didasari oleh adanya motivasi yang baik dalam belajar, maka siswa akan melahirkan hasil belajar IPA yang maksimal.

Berdasarkan analisis dari kedua variabel tersebut yaitu rasa ingin tahu dan motivasi belajar dengan menggunakan bantuan program SPSS 17.0 For Windows, dapat disimpulkan bahwa hipotesis ketiga yang berbunyi "terdapat korelasi yang positif dan signifikan antara rasa ingin tahu $\left(X_{1}\right)$ dan motivasi belajar $\left(X_{2}\right)$ dengan hasil belajar IPA $(Y)$ siswa kelas $V$ di SD Gugus I Pandu Jembrana Tahun Pelajaran 2018/2019" dinyatakan diterima, dengan koefisien kontribusi sebesar 0,817. Jika $r_{\text {hitung }}>r_{\text {tabel }}$ sehingga $0,817>0,156$ maka $\mathrm{H}_{0}$ ditolak. Sehingga dapat dinyatakan terdapat hubungan signifikan. Diketahui persamaan garis regresi $Y=36,197$ $+0,367 X_{1}+0,003 X_{2}$ dengan $F_{\text {hitung }}=157,049$, adapun sumbangan rasa ingin tahu dan motivasi belajar yang dimiliki siswa dengan hasil belajar IPA sebesar $66,8 \%$. Dalam penelitian ini ditemukan korelasi yang positif dan signifikan yang berarti semakin tinggi rasa ingin tahu dan motivasi belajar siswa maka semakin tinggi hasil belajar IPA siswa. Kemendiknas (2010) menyatakan bahwa rasa ingin tahu adalah sikap dan tindakan yang selalu berupaya untuk mengetahui lebih mendalam dan meluas dari sesuatu yang dipelajari, dilihat, dan didengar. Apabila siswa mempunyai sikap dan tindakan yang selalu berupaya untuk mengetahui lebih mendalam dan meluas terhadap sesuatu maka akan memudahkan siswa dalam kegiatan pembelajaran, siswa akan menunjukkan perilaku aktif dalam kegiatan pembelajaran, seperti siswa senang membaca, bertanya, maupun berdiskusi pada proses pembelajaran, dengan peran aktif siswa tersebut maka akan lebih mudah memahami pelajaran. Hal tersebut didukung pendapat dari Jirout \& Klahr (dalam Rohmawati, 2017) yang menyatakan bahwa rasa 
ingin tahu adalah sesuatu yang dapat digunakan guru untuk menumbuhkan, meningkatkan, dan menggunakannya untuk memotivasi anak-anak untuk belajar. Tumbuhnya rasa ingin tahu dan motivasi belajar dalam diri siswa dapat memperlancar kegiatan belajar dan dapat mempermudah siswa dalam menyerap informasi yang disampaikan oleh guru.

\section{Simpulan dan Saran}

Berdasarkan hasil uji hipotesis dan pembahasan dapat disimpulkan bahwa, 1) terdapat korelasi yang positif dan signifikan antara rasa ingin tahu dengan hasil belajar IPA siswa kelas V di SD Gugus I Pandu Jembrana Tahun Pelajaran 2018/2019. Hal tersebut berarti semakin tinggi rasa ingin tahu yang dimiliki oleh siswa maka semakin tinggi pula hasil belajar IPA yang diperoleh; 2) terdapat korelasi yang positif dan signifikan antara motivasi belajar dengan hasil belajar IPA siswa kelas V di SD Gugus I Pandu Jembrana Tahun Pelajaran 2018/2019. Hal tersebut berarti semakin tinggi motivasi belajar yang dimiliki oleh siswa maka semakin tinggi pula hasil belajar IPA yang diperoleh; 3) terdapat korelasi yang positif dan signifikan antara rasa ingin tahu dan motivasi belajar secara bersama-sama dengan hasil belajar IPA siswa kelas V di SD Gugus I Pandu Jembrana Tahun Pelajaran 2018/2019. Hal tersebut berarti semakin tinggi rasa ingin tahu serta motivasi belajar yang dimiliki oleh siswa maka semakin tinggi pula hasil belajar IPA yang diperoleh.

Adapun saran yang dapat disampaikan berdasarkan hasil penelitian ini adalah sebagai berikut, 1) bagi siswa, disarankan untuk meningkatkan rasa ingin tahu dan motivasi belajar yang dimiliki, sehingga siswa dapat menyelesaikan masalah yang dihadapi pada saat pembelajaran dan dapat meningkatkan hasil belajar IPA; 2) bagi guru, disarankan untuk dapat memperhatikan, membimbing dan mengingkatkan rasa ingin tahu dan motivasi belajar siswa. hal itu dilakukan agar siswa aktif saat mengikuti pelajaran IPA dan akan berpengaruh pada peningkatan hasil belajar siswa; 3) bagi sekolah, disarankan untuk dapat mendukung dengan tersedianya sarana dan prasarana penunjang seperti media atau alat-alat peraga untuk meningkatkan rasa ingin tahu dan motivasi belajar siswa; 4) bagi penelitian lain, disarankan dengan hasil penelitian ini digunakan sebagai referensi untuk melakukan penelitian yang sejenis dan bermanfaat bagi pihak-pihak yang melakukan penelitian ini.

\section{Daftar Pustaka}

Agung, A. A. Gede. 2016. Statistika Dasar Untuk Pendidikan. Yogyakarta: Deepublish.

Agung, A. A. Gede. 2016. Statistika Dasar Untuk Pendidikan. Yogyakarta: Deepublish.

Agustiana, Tri, I. G. A \& Tika, I. N. 2017. Konsep Dasar IPA: Aspek Fisika dan Kimia Dilengkapi dengan Model Pembelajaran Berbasis Proyek dan Kearifan Lokal. Yogyakarta: Penerbit Ombak.

Djamarah, Syaiful Bahri. 2002. Psikologi Belajar. Jakarta: PT Rineka Cipta.

Ghufron, M. Nur dan Rini Risnawati S. 2016. Teori-Teori Psikologi. Jogjakarta: Ar-Ruzz Media.

Hamalik, Oemar. 2009. Proses Belajar Mengajar. Jakarta: PT Bumi Angkasa.

Kementrian Pendidikan Nasional. 2010. Pengembangan Pendidikan Budaya dan Karakter Bangsa: Pedoman Sekolah. Jakarta: Balai Penelitian dan Pengembangan Pusat Kurikulum.

Muakhirin, B. 2014. Peningkatan Hasil Belajar IPA Melalui Pendekatan Pembelajaran Inkuiri Pada Siswa SD. Jurnal IImiah Guru Caraka Olah Pikir Edukatif, Nomor 1. 
Mustari, Mohamad. 2014. Nilai Karakter Refleksi Untuk Pendidikan. Jakarta: PT Rajagrafindo Persada.

Rohmawati, Elysa. 2017. Hubungan Motivasi Belajar dan Rasa Ingin Tahu dengan Prestasi Belajar IImu Pengetahuan Sosial SD Bagi Siswa Kelas V Se-Gugus Sendangadi Mlati Sleman. Skripsi (tidak diterbitkan) Program Studi Pendidikan guru Sekolah Dasar, Jurusan Pendidikan Sekolah Dasar, Fakultas IImu Pendidikan, Universitas Negeri Yogyakarta.

Sardiman. 2011. Interaksi \& Motivasi Belajar Mengajar. Jakarta: PT Rajagrafindo Persada.

Sugianto, R.V. 2018. "Pengaruh Self-Congruity, Curiosity, dan Shopping Well-Being terhadap Pola Konsumsi Fast Fashion pada Generasi Millennial di Surabaya". Agora, Volume 6, Nomor 1 (hlm.1-6).

Sugiyono. 2012. Metode Penelitian Pendidikan. Bandung: Alfabeta.

Sukardi. 2012. Metodelogi Penelitian Pendidikan Kompetensi dan Praktiknya. Jakarta: PT Bumi Aksara.

Sukmadinata, Nana Syaodih. 2009. Metode Penelitian Pendidikan. Bandung: PT Remaja Rosdakarya.

Suprijono, Agus. 2009. Cooperative Learning. Yogyakarta: Pustaka Belajar.

Uno, Hamzah B. 2008. Teori Motivasi \& Pengukuran. Jakarta: PT Bumi Aksara. 